\title{
Dietary behaviours and dental fluorosis among Gaza Strip children
}

L. Abuhaloob ${ }^{7}$ and Y. Abed ${ }^{2}$

$$
\begin{aligned}
& \text { السلو كيات من حيث النُظمُ الغذائية وتسمُّم الأسنان بالفلور لدى الأطفال في قطاع غزة عُبة }
\end{aligned}
$$

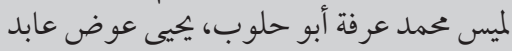

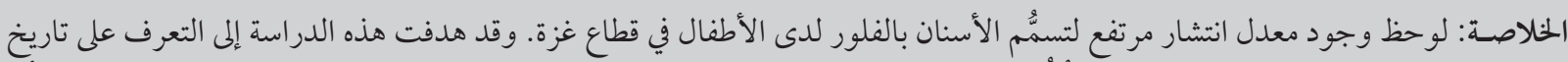

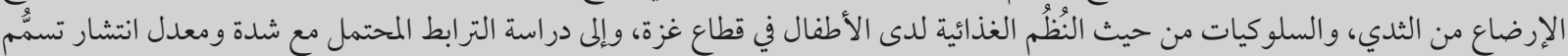

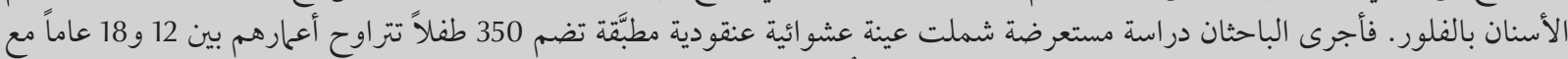

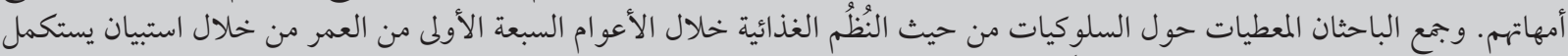

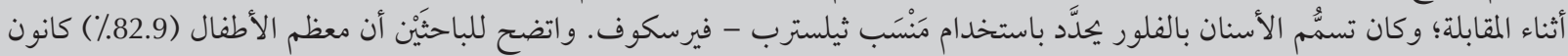

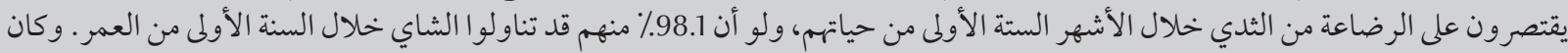

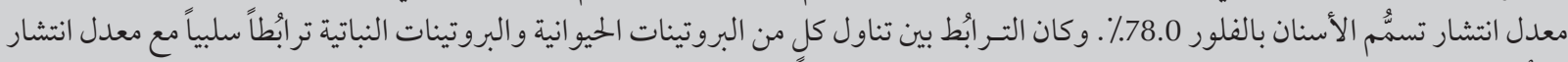

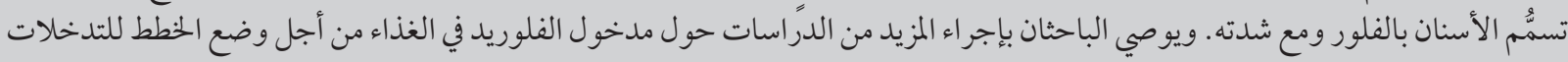

ABSTRACT A high prevalence of dental fluorosis has been identified among children in the Gaza Strip. This study aimed to determine the history of breastfeeding and dietary behaviours among children in the Gaza Strip and to examine potential associations with the prevalence and severity of dental fluorosis. A cross-sectional study recruited a stratified cluster random sample of 350 children aged 12-18 years and their mothers. Data about dietary behaviours in the first 7 years of life were collected by interview questionnaire. Dental fluorosis was determined using the Thyllstrup-Fejerskov index. A majority of children were breastfed exclusively in the first 6 months $(82.9 \%)$ but $98.1 \%$ were given tea in the first year of life. The prevalence of dental fluorosis was $78.0 \%$. Both intake of animal proteins and plant proteins were negatively associated with the prevalence and severity of dental fluorosis. Further studies to investigate fluoride intake is required to plan preventive interventions.

\section{Comportements alimentaires et fluorose dentaire chez des enfants de la Bande de Gaza}

RÉSUMÉ Une prévalence élevée de fluorose dentaire a été observée chez des enfants de la Bande de Gaza. La présente étude visait à déterminer les antécédents d'allaitement au sein et les comportements alimentaires chez des enfants de la Bande de Gaza puis à examiner les associations possibles avec la prévalence et la sévérité de la fluorose dentaire. Une étude transversale a recruté 350 enfants âgés de 12 à 18 ans et leurs mères, formaient un échantillon randomisé et stratifié en grappes. Les données sur les comportements alimentaires au cours des sept premières années de vie ont été recueillies par questionnaire lors d'un entretien. La fluorose dentaire a été déterminée à l'aide de l'indice Thylstrup-Fejerskov. Une majorité des enfants avait été nourrie exclusivement au sein au cours des six premiers mois de vie (82,9\%) mais 98,1\% avaient consommé du thé pendant leur première année. La prévalence de la fluorose dentaire était de 78,0\%. Les apports en protéines animales et végétales étaient négativement associés à la prévalence et la sévérité de la fluorose dentaire. Des études supplémentaires évaluant l'apport en fluor sont requises pour prévoir des interventions préventives. 


\section{Introduction}

Dental fluorosis is an enamel defect of the teeth caused by hypomineralization due to excessive fluoride intake during the period of enamel formation [1]. This period lasts from birth to 5 years old for anterior permanent teeth and to 13 years old for all permanent teeth [2].

Children in the Gaza Strip have suffered from the problem of dental fluorosis for decades. In 1991, Sansur first identified this problem and emphasized its seriousness [3]. In 1999, the prevalence of dental fluorosis in 7 th grade (12-year-old children) in Rafah (60.0\%) was the highest, followed by Khan Younis (50.5\%), while in North Gaza, where the fluoride concentration was very low in drinking water, it did not exceed $7.1 \%$ [4]. Recently, a high prevalence of dental fluorosis (60\%) was detected among children of school age in the Gaza Strip [5].

Severe dental fluorosis in the Gaza Strip is multi-factorial. A World Health Organization report stated that drinking water, foods, fluoridated toothpaste and air pollution with fluoride are sources of fluoride exposure [6]. It was pointed out that there is a potential association between breastfeeding and a lower risk of dental fluorosis [7-10]. Previous studies suggested that malnutrition could be a risk factor that increases the prevalence and severity of dental fluorosis [6,8-11]. In the Islamic Republic of Iran a studies found that foods had a considerable contribution (up to $22 \%$ ) to the total dietary fluoride intake among children [12], and in Brazil foods were identified one of the main sources of fluoride along with water to the total dietary fluoride intake of preschool children [13]. It has also been found that drinking tea and eating fish may increase the risk of dental fluorosis [14].

There are no studies investigating the relationship between nutrition and oral and dental disorders in Palestine. Thus, the objectives of this paper were to investigate the history of breastfeeding during early childhood and the history of nutrition behaviours during the first 7 years of age, to estimate the prevalence and severity of dental fluorosis and to examine the potential associations between prevalence and severity of dental fluorosis and breastfeeding practices and nutrient consumption among 12-18-year-old children in the Gaza Strip.

\section{Methods}

\section{Study design and sample}

This was a community-based, crosssectional study of school-age children. The sample size, according to Epi Info, version 6 statistical program, was 350 children. The anticipated prevalence of dental fluorosis used for sample size estimation was $60 \%$ with confidence interval 5\%. A proportional, stratified cluster random sample of children were selected from home settings in the 5 Gaza governorates (North Gaza, Gaza City, Midzone, Khan-Younis, and Rafah). Each selected cluster was served by water supplies of known wells and the fluoride concentration of municipal well supplying tap water for each child's home was known from the governorate municipality. Children aged 12-18 years old who were born and had spent their first 7 years of life in the same house at the time of the study and who were drinking from the municipal drinking water supply were recruited.

\section{Data collection}

Children were interviewed with their mothers. The researcher used a questionnaire to collect data on the history of breastfeeding, baby formula usage during child infancy and frequency of child's consumption of different foods and milk and tea during the first 7 years of life. Consumption of animal proteins (e.g. meat, chicken, fish, cheese), plant proteins (e.g. nuts, peas, beans, rice, wheat, maize), calcium-rich foods (e.g. milk, yogurt, cheese) and vitamin C from fruits (e.g. oranges) and vegetables (e.g. spinach, chilli) were determined based on mothers' estimation of the children's intake. Consumption was classified as high (> 3 times/week), moderate (2-3 times/week) or low ( $\leq 1$ time/week). In some cases the data were analysed in 2 groups, age 1-3 years, when most children are still at home, and 4-7 years, the age when children in Gaza Strip start to attend nurseries and kindergartens and when a change in eating behaviours would be expected.

The prevalence and severity of dental fluorosis was determined using the Thyllstrup-Fejerskov index (TFI) of dental fluorosis [15]. The researcher asked the child to brush his/her teeth, and then examined the teeth in normal daylight and recorded the TFI score of the buccal surfaces of all permanent teeth, including the permanent molars.

The study questionnaire was revised and validated by 12 experts in psychology, environment, nutrition, public health, dentistry, and dental public health. Then the questionnaire was piloted among 10 children with their mothers from different areas in all Gaza governorates. The pilot sample was excluded from the study.

Approval for the study was obtained from the Helsinki ethics committee in the Gaza Strip and the Palestinian Ministry of Health. Informed consent was obtained from the children and their families, after complete explanation of the purpose of the research, reassurances about confidentiality and that participation in the study was optional.

\section{Analysis}

SPSS, version 14.0 for used data coding, entry and analysis. Cross-tabulations between dental fluorosis and each of the potential risk factors were developed. 
The relationship between variables was examined using the chi-squared test or Fisher test. Results were considered statistically significant at $P$-value $<0.05$.

\section{Results}

\section{Baby formula usage and breastfeeding during infancy}

The majority (82.9\%) of the mothers practised exclusive breastfeeding at least in the first 6 months of the child's life (Table 1). Among mothers who started giving formula milk to the child $61.9 \%$ started it in the first 1-2 months; 61 $(96.8 \%)$ of these mothers used tap water to reconstitute infant formula milk and the rests used mineral water.

\section{Milk consumption}

The percentage of the children who started to milk drinking at age $16+$ months was $51.1 \%$. Of these children $51.6 \%$ had $3+$ cups of milk per day between $1-3$ years of age and $92.7 \%$ had 1 cup of milk per day between 4-7 years old. Only artificial milk was consumed by $80.8 \%$ of these children, and of those who had artificial milk it was reconstituted in tap water for $99.4 \%$.

\section{Tea consumption}

Many children (44.1\%) started to drink tea early, as young as 1 year old. At ages 1-3 years a majority (98.1\%) drank only 1 cup of tea per day while at ages 4-7 years $58.1 \%$ drank $1-2$ cups of tea per day. Tea was prepared with tap water for 98.6\% of these children (Table 1).

\section{Food consumption}

Just over half of children (52.4\%) ate fish $<3$ times per month (Table 2). Consumption of animal proteins was moderate for $48.6 \%$ and consumption of plant proteins was moderate for $44.3 \%$. The study found that $78.9 \%$ of children had high consumption of calcium-rich foods. A high consumption of vitamin $\mathrm{C}$ from fruits was reported (80.3\%) whereas only $55.7 \%$
Table 1 Breastfeeding, milk and tea drinking of children aged 12-18 years in Gaza Strip during their first 7 years of life

Variable

Exclusively breastfed for first 6 months

Yes

No.

$\%$

290

82.9

No

17.1

Total

100.0

Month when formula was started

$1-2$

61.9

3+

Total

100.0

Month when milk drinking was started

1-15

48.9

$16+$

Total

100.0

No. of cups of milk drunk per day age 1-3 years

1-2

48.4

3+

51.6

Total

100.0

No. of cups of milk drunk per day age 4-7 years

1

92.7

2

Total

100.0

Type of milk drunk

Artificial milk

Animal milk

80.8

Artificial and animal milk

14.3

Total

4.9

100.0

If artificial milk, type of water used to reconstitute

Tap water

99.4

Mineral water

0.6

Total

100.0

Year in which tea drinking was started

1

$2+$

Total

100.0

No. of cups of tea drunk per day age 1-3 years

1

$2+$

Total

100.0

No. of cups of tea drunk per day age 4-7 years

1-2 155

$3+$

Total

100.0

Type of water used to prepare tea

Tap water

98.6

Mineral water

Total

100.0

a In addition to the 60 mothers who used formula in the child's first 6 months, 3 mothers started to use formula during the 7th to 9th months. 


\begin{tabular}{|c|c|c|}
\hline \multirow{2}{*}{\multicolumn{3}{|c|}{$\begin{array}{l}\text { Table } 2 \text { Food consumption of children a } \\
\text { first } 7 \text { years of life } \\
\text { Variable } \\
\text { No. of times fish consumed per month }\end{array}$}} \\
\hline & & \\
\hline $1-2$ & 150 & 52.4 \\
\hline $3+$ & 136 & 47.6 \\
\hline Total & 286 & 100.0 \\
\hline \multicolumn{3}{|c|}{$\begin{array}{l}\text { Consumption of animal proteins (e.g. meat, } \\
\text { chicken, fish, cheese) }\end{array}$} \\
\hline High & 100 & 28.6 \\
\hline Moderate & 170 & 48.6 \\
\hline Low & 80 & 22.9 \\
\hline Total & 350 & 100.0 \\
\hline \multicolumn{3}{|c|}{$\begin{array}{l}\text { Consumption of plant proteins (e.g. nuts, peas, } \\
\text { beans, rice, wheat. maize) }\end{array}$} \\
\hline High & 107 & 30.6 \\
\hline Moderate & 155 & 44.3 \\
\hline Low & 88 & 25.1 \\
\hline Total & 350 & 100.0 \\
\hline \multicolumn{3}{|c|}{$\begin{array}{l}\text { Consumption of calcium-rich foods (e.g. milk, } \\
\text { yogurt, cheese) }\end{array}$} \\
\hline High & 276 & 78.9 \\
\hline Moderate & 47 & 13.4 \\
\hline Low & 27 & 7.7 \\
\hline Total & 350 & 100.0 \\
\hline \multicolumn{3}{|c|}{$\begin{array}{l}\text { Consumption of vitamin Cfrom fruits (e.g. } \\
\text { oranges) }\end{array}$} \\
\hline High & 281 & 80.3 \\
\hline Moderate & 54 & 15.4 \\
\hline Low & 15 & 4.3 \\
\hline Total & 350 & 100.0 \\
\hline \multicolumn{3}{|c|}{$\begin{array}{l}\text { Consumption of vitamin C from vegetables (e.g. } \\
\text { spinach, chilli) }\end{array}$} \\
\hline High & 195 & 55.7 \\
\hline Moderate & 34 & 9.7 \\
\hline Low & 121 & 34.6 \\
\hline Total & 350 & 100.0 \\
\hline
\end{tabular}

had high consumption of vitamin $\mathrm{C}$ from vegetables.

\section{Prevalence and severity of dental fluorosis}

According to the TFI scores, 273 children had signs of dental fluorosis, giving a prevalence of dental fluorosis among this sample of Palestinian children in Gaza Strip of $78.0 \%$. TFI scores were 1-4 (moderate fluorosis) for $63.4 \%$ and 5-8 (severe fluorosis) for $14.6 \%$. or after that; and whether mineral or tap water was used to reconstitute infant formula. There were also no statistical significant differences in the rate of dental fluorosis for children's consumption habits during the first 7 years of life whether: drinking $<2$ or $2+$ cups of milk during; starting to drink tea at age year 1 or after year 2 ; eating fish $<3$ or $3+$ times per month; consuming low or high amounts of calcium-rich foods; consuming low or high amounts vitamin $\mathrm{C}$ as fruits; and consuming low or high amounts of vitamin $C$ as vegetables a during the first 7 years of life.

In contrast, there were negative high statistical significant associations between dental fluorosis level and consumption of animal proteins and plant proteins. In other words, a higher consumption of animal proteins or plant proteins during the first 7 years of the child's life significantly decreased dental fluorosis prevalence and severity ( $P=0.005$ and $P=0.026$ respectively) (Table 3).

\section{Discussion}

Formula milk consumption during first 6 months of infancy could increase the risk of dental fluorosis $[10,16]$. In a non-fluoridated rural area of Ontario, Canada, a study found that when the breastfeeding period increased from $<6$ months, 6-12 months, to $>12$ months, the dental fluorosis prevalence among 752 children decreased significantly from $27.2 \%, 19.6 \%$ to $13.8 \%$ respectively. Dental fluorosis prevalence was $87 \%$ among children having formula reconstituted with tap water [8]. Marshall et al. determined that using formula reconstituted with fluoridated water and lower intake of human milk and cow's milk which have low fluoride concentrations (0.005-0.010 ppm fluoride and 0.03-0.06 ppm fluoride respectively) increased the risk of dental fluorosis among children at the early ages [9]. Buzalaf et al. advised avoiding excessive 


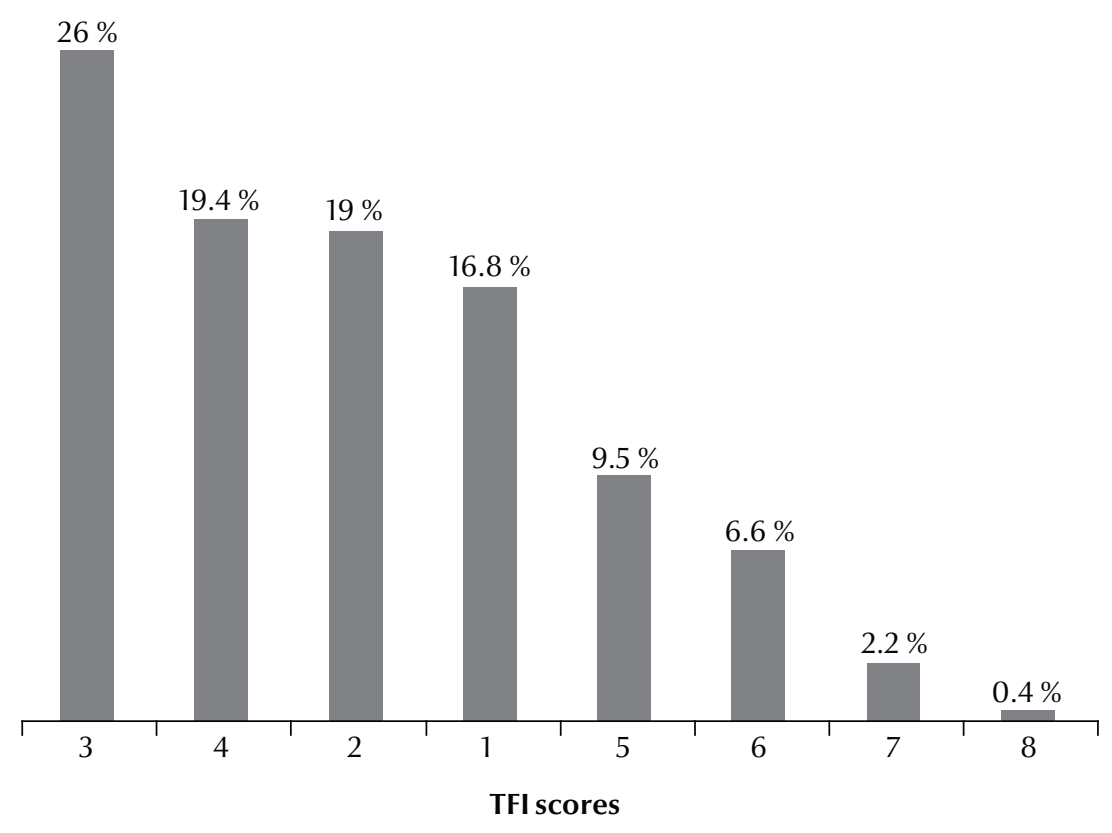

Figure 1 Prevalence and severity of dental fluorosis among children aged 12-18 years in Gaza Strip (TFI = Thyllstrup-Fejerskov index)

fluoride intake by using fluoridated water with $\geq 1 \mathrm{ppm}$ fluoride concentration to dilute powdered infant formulas [17]. In Poland, it was found that the fluoride concentration in 29 brands of powdered formulas was low (mean 29.0 $\mu \mathrm{g} / 100 \mathrm{~g}$ ) but that the fluoride intake would exceed the recommended daily intake for infants when reconstituting the formula milk with water having > $0.5 \mathrm{ppm}$ of fluoride [18]. Moynihan et al. estimated the fluoride concentration of infant milk formula available in the United Kingdom to be between 0.03 and $1.32 \mathrm{mg} / \mathrm{g}$ in non-reconstituted formula powders [19]. This fluoride concentration slightly increases to $0.13-1.19 \mathrm{mg} / \mathrm{L}$ in infant formula reconstituted with water of $0.1 \mathrm{mg} / \mathrm{L}$ fluoride concentration, while a remarkable rise in fluoride concentration to about $1.48-5.22 \mathrm{mg} / \mathrm{L}$ was observed when formula was reconstituted with water of 1 ppm fluoride concentration. As a result, infant fluoride intake from formula prepared with low and optimally fluoridated water was approximately $0.01-0.08$ and $0.13-0.58 \mathrm{mg} / \mathrm{kg}$ body weight/day respectively. However, the fish fillets did not appear to be responsible for the prevalence and severity of dental fluorosis among residents [22]. The later findings of Gikunju et al. may support the findings of the current study in which we found that eating fish $<3$ or $3+$ times per month did not indicate significant differences in the risk of dental fluorosis [22].

A study by Sansur among UNRWA schoolchildren in the Gaza Strip showed that schoolchildren in all regions drank approximately 3 cups of tea per day on average [3]. The highest (3.19 cups) was in Rafah and the lowest (2.4 cups) was in Bani Suhila. Consistent with our results, Shomer et al. demonstrated that children in Gaza Strip were consuming tea in an early age $[5]$. We found that $44.1 \%$ of children were given tea since the first year of age. However, there were no statistically significant differences in the prevalence of dental fluorosis between children receiving tea before year 2 of life and who received it after that. This contrasts with the suggestion that tea could be a source of high fluoride intake [14], as illustrated in a study showing that brick tea was one of the factors responsible for dental fluorosis in Tibetan children in the natural reserve of Mount Qomolangma [23].

Whitford has argued that fluoride absorption is inversely related to dietary calcium intake, because dietary calcium at high concentrations may cause net fluoride secretion into the gastrointestinal tract [24]. In the present study, however, consuming more foods rich in calcium (e.g. milk, yogurt, cheese) was not a protective factor for dental fluorosis.

In the current study, there was a negative highly statistically significant association between the level of consumption each of animal proteins or plant proteins during the first 7 years and dental fluorosis prevalence and severity. In North Tanzania, a study of 165 schoolchildren (aged 6-18 years) found that the prevalences of moderate 
Table 3 Associations between dietary behaviours and dental fluorosis of children aged 12-18 years in Gaza Strip during the first 7 years of age based on Thyllstrup-Fejerskov index (TFI) scores

\begin{tabular}{|c|c|c|c|c|c|c|c|c|}
\hline \multirow[t]{3}{*}{ Variable } & \multirow{3}{*}{$\begin{array}{l}\text { Total } \\
\text { No. }\end{array}$} & \multicolumn{6}{|c|}{ TFI score of dental fluorosis } & \multirow[t]{3}{*}{$P$-value } \\
\hline & & \multicolumn{2}{|c|}{$\mathbf{0}$} & \multicolumn{2}{|c|}{$1-4$} & \multicolumn{2}{|c|}{$5-8$} & \\
\hline & & No. & $\%$ & No. & $\%$ & No. & $\%$ & \\
\hline Total & 350 & 77 & 22.0 & 222 & 63.4 & 51 & 14.6 & \\
\hline Exclusively breastfed for first 6 month & & & & & & & & 0.220 \\
\hline Yes & 290 & 64 & 22.1 & 188 & 64.8 & 38 & 13.1 & \\
\hline No & 60 & 13 & 21.7 & 34 & 56.7 & 13 & 21.7 & \\
\hline Month when formula was started & & & & & & & & 0.678 \\
\hline $1-2$ & 39 & 9 & 23.1 & 22 & 56.4 & 8 & 20.5 & \\
\hline $3+$ & 24 & 4 & 16.7 & 13 & 54.2 & 7 & 29.2 & \\
\hline Type of water used to reconstitute formula & & & & & & & & 0.373 \\
\hline Tap water & 61 & 12 & 19.7 & 0 & 0 & 49 & 80.3 & \\
\hline Minimal water & 2 & 1 & 50.0 & 0 & 0 & 1 & 50.0 & \\
\hline No. of cups of milk drunk/day age 1-3 years & & & & & & & & 0.791 \\
\hline $1-2$ & 88 & 20 & 22.7 & 56 & 63.6 & 12 & 13.6 & \\
\hline $3+$ & 94 & 22 & 23.4 & 56 & 59.6 & 16 & 17.0 & \\
\hline No. of cups of milk drunk/day age 4-7 years & & & & & & & & 0.228 \\
\hline 1 & 114 & 27 & 23.7 & 0 & 0 & 87 & 76.3 & \\
\hline 2 & 9 & 4 & 44.4 & 0 & 0 & 5 & 55.6 & \\
\hline Year in which tea drinking was started & & & & & & & & 0.099 \\
\hline 1 & 124 & 20 & 16.1 & 78 & 62.9 & 26 & 21.0 & \\
\hline $2+$ & 157 & 34 & 21.7 & 104 & 66.2 & 19 & 12.1 & \\
\hline No. of times fish consumed per month & & & & & & & & 0.240 \\
\hline $1-2$ & 150 & 34 & 22.7 & 90 & 60.0 & 26 & 17.3 & \\
\hline $3+$ & 136 & 26 & 19.1 & 94 & 69.1 & 16 & 11.8 & \\
\hline Consumption of animal proteins & & & & & & & & 0.005 \\
\hline High & 100 & 31 & 31.0 & 56 & 56.0 & 13 & 13.0 & \\
\hline Moderate & 170 & 23 & 13.5 & 122 & 71.8 & 25 & 14.7 & \\
\hline Low & 80 & 23 & 28.8 & 44 & 55.0 & 13 & 16.3 & \\
\hline Consumption of plant proteins & & & & & & & & 0.026 \\
\hline High & 107 & 35 & 32.7 & 60 & 56.1 & 12 & 11.2 & \\
\hline Moderate & 155 & 27 & 17.4 & 105 & 67.7 & 23 & 14.8 & \\
\hline Low & 88 & 15 & 17.0 & 57 & 64.8 & 16 & 18.2 & \\
\hline Consumption of calcium-rich foods & & & & & & & & 0.482 \\
\hline High & 276 & 63 & 22.8 & 175 & 63.4 & 38 & 13.8 & \\
\hline Moderate & 47 & 7 & 14.9 & 33 & 70.2 & 7 & 14.9 & \\
\hline Low & 27 & 7 & 25.9 & 14 & 51.9 & 6 & 22.2 & \\
\hline Total & 350 & 77 & 22.0 & 222 & 63.4 & 51 & 14.6 & \\
\hline Consumption of vitamin $C$ from fruits & & & & & & & & 0.110 \\
\hline High & 281 & 67 & 23.8 & 175 & 62.3 & 39 & 13.9 & \\
\hline Moderate & 54 & 5 & 9.3 & 40 & 74.1 & 9 & 16.7 & \\
\hline Low & 15 & 5 & 33.3 & 7 & 46.7 & 3 & 20.0 & \\
\hline $\begin{array}{l}\text { Consumption of vitamin C from } \\
\text { vegetables }\end{array}$ & & & & & & & & 0.45 \\
\hline High & 195 & 43 & 22.1 & 121 & 62.1 & 31 & 15.9 & \\
\hline Moderate & 34 & 4 & 11.8 & 26 & 76.5 & 4 & 11.8 & \\
\hline Low & 121 & 30 & 24.8 & 75 & 62.0 & 16 & 13.2 & \\
\hline
\end{tabular}


(TFI score 1-4 score) and severe (TFI score 5-9) dental fluorosis were 67\%, and $21 \%$ respectively among vegetarian children, and were lower than the prevalences of moderate and severe dental fluorosis among non-vegetarian children (95\% and 35\% respectively) [25]. This could explain the negative significant associations between the level of consuming plant protein and dental fluorosis in the current study. As a result it could be argued that some dietary behaviours could be associated with dental fluorosis in addition to the existence of excessive fluoride in drinking water and they should be considered when investigating the associated risk factors to dental fluorosis in developing and undeveloped courtiers and developing interventions for prevention of fluorosis.

In conclusion, it is important to have information on the intake of fluoride by children living in the Gaza Strip and to identify the children at higher risk of dental fluorosis at the ages of tooth development. Such information will enable the development of an appropriate preventive strategy to reduce the fluoride intake to a suitable level in order to prevent dental fluorosis and other potential health hazards.

Competing interests: None declared.

\section{References}

1. Achievements in public health, 1900-1999: fluoridation of drinking water to prevent dental caries. Morbidity and Mortality Weekly Report, 1999, 48:933-940.

2. Aoba T, Fejerskov O. Dental fluorosis: chemistry and biology. Critical Reviews in Oral Biology and Medicine, 2002, 13:155-170.

3. Sansur R. Naturally occurring fluorides in underground water and their effect on dental fluorosis among UNRWA school children in the Gaza Strip. Palestine, Birzeit University, 1991.

4. The status of health in Palestine: annual report 1999. Palestine, Ministry of Health, 2000.

5. Shomar B et al. Fluorides in groundwater, soil and infused black tea and the occurrence of dental fluorosis among school children of the Gaza strip. Journal of Water and Health, 2004, 2:23-35.

6. Water sanitation and health. Water-related diseases - Fluorosis. Geneva, World Health Organization, 2011 (http://www. who.int/water_sanitation_health/diseases/fluorosis/en/, accessed 19 December 2011).

7. Buzalaf MA et al. Risk of fluorosis associated with infant formulas prepared with bottled water. Journal of Dentistry for Children, 2004, 71:110-113.

8. Brothwell $\mathrm{D}$, Limeback $\mathrm{H}$. Breastfeeding is protective against dental fluorosis in a nonfluoridated rural area of Ontario, Canada. Journal of Human Lactation, 2003, 19:386-390.

9. Marshall TA et al. Associations between intakes of fluoride from beverages during infancy and dental fluorosis of primary teeth. Journal of the American College of Nutrition, 2004, 23:108-116.

10. Teixeira AK et al. [Analysis of protection or risk factors for dental fluorosis in 6 to 8 year-old children in Fortaleza, Brazil] Análise dos fatores de risco ou de proteção para fluorose dentária em crianças de 6 a 8 anos em Fortaleza, Brasil. Revista Panamericana de Salud Pública, 2010, 28:421-428.

11. Rugg-Gunn AJ, Al-Mohammadi SM, Butler TJ. Effects of fluoride level in drinking water, nutritional status, and socio-economic status on the prevalence of developmental defects of dental enamel in permanent teeth in Saudi 14-year-old boys. Caries Research, 1997, 31:259-267.

12. Zohouri FV, Rugg-Gunn AJ. Sources of dietary fluoride intake in 4-year-old children residing in low, medium and high fluoride areas in Iran. International Journal of Food Sciences and Nutrition, 2000, 51:317-326.

13. Rodrigues MHC et al. Dietary fluoride intake by children receiving different sources of systemic fluoride. Journal of Dental Research, 2009, 88:142-145.

14. Wondwossen F et al. Sociodemographic and behavioural correlates of severe dental fluorosis. International Journal of Paediatric Dentistry, 2006, 16:95-103.

15. Thylstrup A, Fejerskov O. Clinical appearance of dental fluorosis in permanent teeth in relation to histologic changes. Community Dentistry and Oral Epidemiology, 1978, 6:315-328.

16. Levy SM et al. Associations between fluorosis of permanent incisors and fluoride intake from infant formula, other dietary sources and dentifrice during early childhood. Journal of the American Dental Association, 2010, 141:1190-1201.

17. Buzalaf $\mathrm{MA}$ et al. Fluoride content of infant formulas prepared with deionized, bottled mineral and fluoridated drinking water. ASDC Journal of Dentistry for Children, 2001, 68:37-41, 10.

18. Opydo-Szymaczek J, Opydo J. Dietary fluoride intake from infant and toddler formulas in Poland. Food and Chemical Toxicology, 2011, 49:1759-1763.

19. Moynihan $\mathrm{P}$ et al. Fluoride content of and estimated fluoride intake from milk formula. Journal of Dental Research, 2004, Special Issue B:1438.

20. Chen YC et al. Nutrition survey in dental fluorosis-afflicted areas. Fluoride, 1997, 30:77-80.

21. Bhargava D, Bhardwaj N. Study of fluoride contribution through water and food to human population in fluorosis endemic villages of north-eastern Rajasthan. African Journal of Basic and Applied Sciences, 2009, 1(3-4):55-58.

22. Gikunju JK et al. Fluoride in fish from lakes of Great Rift Valley, Kenya. Ecology of Food and Nutrition, 1992, 27:85-90.

23. Cao $\mathrm{J}$ et al. Varied ecological environment and fluorosis in Tibetan children in the nature reserve of Mount Qomolangma. Ecotoxicology and Environmental Safety, 2001, 48:62-65.

24. Whitford GM. Determinants and mechanisms of enamel fluorosis. Ciba Foundation Symposium, 1997, 205:226-241.

25. Awadia AK et al. Vegetarianism and dental fluorosis among children in a high fluoride area of northern Tanzania. International Journal of Paediatric Dentistry, 1999, 9:3-11. 